\title{
Hypoxia- and acidosis-driven aberrations of secreted microRNAs in endometrial cancer in vitro
}

\author{
JULIA EISMANN ${ }^{1,4}$, MARC HIRSCHFELD ${ }^{1,2,4}$, THALIA ERBES ${ }^{1,4}$, GERTA RÜCKER ${ }^{3}$, \\ MARKUS JÄGER $^{1,4}$, ANDREA RITTER ${ }^{1,4}$, DANIELA WEISS ${ }^{1,4}$, \\ GERALD GITSCH $^{1,4}$ and SEBASTIAN MAYER ${ }^{1,4}$ \\ ${ }^{1}$ Department of Obstetrics and Gynecology, Medical Center - University of Freiburg, Freiburg; ${ }^{2}$ Institute of Veterinary \\ Medicine, Georg-August-University Goettingen, Goettingen; ${ }^{3}$ Institute for Medical Biometry and Statistics, \\ Medical Center - University of Freiburg; ${ }^{4}$ Faculty of Medicine, University of Freiburg, Freiburg, Germany
}

Received March 17, 2017; Accepted May 19, 2017

DOI: $10.3892 /$ or.2017.5717

\begin{abstract}
Due to their post-transcriptional regulatory impact on gene expression, microRNAs (miRNA, miRs) influence decisively cellular processes of differentiation, proliferation and apoptosis. In oncogenic pathways various miRNAs exert either oncogenic or tumor suppressor activities in a stage-specific manner. Dysregulation of miRNA expression pattern has been associated with several human cancers including endometrial cancer (EC). In the present study, expression profile alterations of EC associated secreted miRNAs were determined under the microenvironmental stress situations hypoxia and acidosis occurring in tumor progression and metastasis. The potential influence of hypoxia and acidosis vs. control conditions on the expression levels of 24 EC-relevant miRNA types was quantitatively accessed via real-time PCR in three established EC in vitro models. Expression data were analyzed statistically. In vitro application of hypoxia resulted in downregulation of miR-15a, miR-20a, miR-20b and miR-128-1 in Ishikawa cells (type I EC) and upregulation of miR-21 in EFE-184 cells (type I EC). Acidosis triggered upregulation of tumor promoting miR125b in AN3-CA cell (type II EC), whereas in Ishikawa cells (type I EC) miRNAs with tumor suppressive function were found altered in divergent directions, both up- (let-7a) and down- (miR-22) regulated. Our current findings emphasize the functional importance of secreted miRNAs in the immediate response of EC cells to exogenic stress situations such as the typical tumor epiphenomena hypoxia and acidosis. Focusing on the specific potential of secreted, thus circulating miRNA molecules, alterations in expression levels not only influence intracellular gene expression and signaling cascades, but also
\end{abstract}

Correspondence to: Dr Sebastian Mayer, Department of Obstetrics and Gynecology, Medical Center - University of Freiburg, Hugstetterstr. 55, 79106 Freiburg, Germany

E-mail: sebastian.mayer@uniklinik-freiburg.de

Key words: microRNA, endometrial cancer, hypoxia, acidosis, regulation, secretion transfer the induction of (tumor)biological cellular changes to adjacent cells.

\section{Introduction}

Due to the vast functional multiplicity, microRNAs (miRNA, miRs) shaped up as the most important class of small non-coding RNAs (ncRNAs) (1) playing a crucial role in post-transcriptional regulation of gene expression and signaling pathways. Mature miRNA is incorporated into the RNA-induced silencing complex (RISC) which usually leads to mRNA degradation and translational repression $(2,3)$. Using this mechanism, miRNAs influence cellular processes of differentiation, proliferation and apoptosis. Due to their ability to participate in modulation of oncogenic pathways miRNAs are important key regulators of tumor suppressor genes and oncogenes (4-6). A widespread dysregulation of miRNAs is observed in a variety of human cancers (7-9).

miRNA molecules can be localized intracellularly or, after secretion, circulate in the extracellular compartment (10). Release of miRNA in the extracellular compartment can take place as passive leakage from cells or can include active export by apoptotic bodies, high-density lipoproteins, microvesicles, exosomes and protein complexes (11-13). Argonaute complexes, which are regular complexes of the RNA silencing machinery, and Nucleosphosmin-1 play a predominant role in protein-complex dependent secretion of miRNAs (14). In this context, miRNA packaging and extracellular export is mediated by Nucleophosmin-1, which also acts as a protector from RNA degradation $(11,15)$. For exosomal miRNA secretion, Zhang et al reported trafficking and sorting mechanisms which play an important role in cellcell communication processes (16).

Endometrial cancer (EC) is the most common gynecologic malignancy, accounting for $7 \%$ of all cancers in women in the United States (17). Incidence as well as death rate of EC has increased during recent years (18). EC can be subclassified into two categories: type I cancers are usually well to moderately differentiated, estrogen-related endometrial carcinomas (EEC) with good prognosis, which are associated with endometrial hyperplasia, whereas type II cancers are non-estrogenic high 
grade serous or clear cell carcinomas with poor prognosis, which are associated with atrophic endometrium. Molecular characteristics of EC cells do not always correlate with the traditional classification systems which have been based on clinical features or on histopathological findings (19-21).

MiRNAs have been shown to participate in regulation of endometrial growth and differentiation (22-26) and carcinogenesis of the endometrium has been associated with alterations in miRNA expression pattern. Furthermore, distinct miRNA signatures characterizing EC subtypes have been described (24,27-30). Since miRNAs have been shown to be stable molecules which are well preserved in serum and other body fluids $(21,31,32)$ their use as promising non-invasive biomarkers in EC is under investigation (21). Jia et al reported in 2013 the identification of four serum-based miRNA types as potential non-invasive biomarkers for endometrioid endometrial cancer (32).

Alterations in miRNA expression patterns were also found in tumor cells exposed to stressors such as extracellular hypoxia and acidosis $(33,34)$. However, there are no reports on miRNA expression under hypoxic or acidic conditions in EC cells. To our knowledge, to date there are only few studies investigating miRNA expression aberrations under the influence of hypoxia in endometriosis (35-37).

Hypoxia is an important regulatory factor in tumor growth and induces transcriptional cascades that promote a more aggressive tumor phenotype. In order to survive and proliferate in a hypoxic microenvironment tumor cells undergo genetic and adaptive changes and release substances that affect the microenvironment to promote tumor angiogenesis $(38,39)$. These processes contribute to a malignant phenotype and aggressive tumor behavior as well as metastasis (38).

Kulshreshtha et al suggested that hypoxia may represent a key contributing stress factor for microRNA alterations in cancer. In colon and breast cancer cell lines, expression of specific miRNAs was altered under hypoxia (40). Hua et al described a miRNA directed regulation of VEGF and other angiogenetic factors under hypoxia in cells from a human nasopharyngeal carcinoma cell line (41).

Acidosis of the extracellular microenvironment is a consequence of increased glycolysis due to the adaption of tumor cells to prolonged periods of hypoxia. Cancer cells suffering oxygen deprivation use the glycolytic pathways to maintain their ATP level for survival and proliferation. Acidification of the peritumoral microenvironment induces necrosis and apoptosis of normal cells, thus creating space into which the tumor cells may proliferate (42). Acidosis promotes tumor invasion by degradation of the extracellular matrix through the discharge of proteolytic enzymes (43). Lowered $\mathrm{pH}$ levels also inhibit natural killer cell activity and the cytolytic activity of cytotoxic T-lymphocytes, therefore causing a diminished immune response to tumor antigens (44). This way, acidosis facilitates tumor progression and the development of invasive phenotypes. Furthermore, acidosis and hypoxia have been associated with resistance to therapeutic strategies such as multi-drug resistance and poor prognosis (45).

The present study investigated the quantitative expression of 24 different miRNAs secreted by EC cells in vitro in response to the exogenic stimuli hypoxia and acidosis. The panel of 24 specific miRNA types (let-7a, let-7b, let-7d, let-7i,
miR-10a, -10b, -15a, -15b, -17, -19b, -20a, -20b, -21, -22, -26.1, $27 \mathrm{a},-29 \mathrm{c},-30 \mathrm{~b},-92 \mathrm{a},-125 \mathrm{~b},-128-1,-135 \mathrm{~b},-200 \mathrm{c},-222)$ was collocated based on a targeted pre-selection process focusing on EC-associated circulating miRNAs with tumor biological, diagnostic and therapeutic relevance. An initial screening expression analysis attested that all 24 secreted miRNAs were stably detectable in the supernatant of the selected three EC in vitro models (Ishikawa, EFE 184, AN3-CA; see Materials and methods for details). The current data on the tumor biological relevance of the selected miRNA types is summarized in Table I (1,25,26,28-30,41,46-75).

\section{Materials and methods}

Cell culture conditions and treatments. Established endometrial cancer cell lines Ishikawa i) (type I, well differentiated, ER and PR positive) (76). AN3-CA ii) (type II, poorly differentiated, ER negative) and EFE-184 iii) (type I) were incubated in humidified atmosphere at $37^{\circ} \mathrm{C}$ and $5 \% \mathrm{CO}_{2}$ in i) RPMI-1640 or (ii and iii) DMEM/F12 medium supplemented with $10 \%$ newborn calf serum $\left(\mathrm{Gibco}^{\mathrm{TM}}\right.$, Thermo Fisher Scientific, Karlsruhe, Germany), 1\% HEPES buffer (Gibco) and $100 \mathrm{U} / \mathrm{ml}$ penicillin/streptomycin (Sigma-Aldrich ${ }^{\circledR}$, Taufkirchen, Germany).

For the induction of stress conditions hypoxia and acidosis cells were subcultured in $25 \mathrm{~cm}^{2}$ cell culture flasks and grown for $18 \mathrm{~h}$. Hypoxia was induced by incubating cells in hypoxic chamber $\left(<3 \% \mathrm{CO}_{2}\right)$ for a period of $18 \mathrm{~h}$ overnight. For acidosis exposure, cells were treated with $0.2 \%$ lactic acid in cell culture media and incubated for $48 \mathrm{~h}$ at $37^{\circ} \mathrm{C}$. Cells incubated under standard conditions in parallel served as controls. Following treatment, $2 \mathrm{ml}$ of culture media (supernatant) were harvested and immediately processed. All experiments were performed in triplicates.

Total RNA isolation. Total RNAs from supernatant of cultured cells were isolated by using the innuPREP Micro RNA Kit (Analytic Jena AG, Jena, Germany) according to the manufacturer's protocol. Assessment of RNA quantity was done by UV-spectrometry (NanoDrop ND1000 (PEQLAB, Erlangen, Germany). Until further processing RNA samples were stored at $-80^{\circ} \mathrm{C}$.

Reverse transcription $(R T)$ and quantitative $P C R$. The reaction mixture of RT consists of $4 \mu 1$ Maxima RT-buffer (Thermo), $1 \mu 1$ $5 \mu \mathrm{M}$ poly(T) adaptor primer (Biomers, Konstanz, Germany), $1 \mu 15 \mathrm{mM}$ dNTPs (Jena Bioscience, Jena, Germany), $0.25 \mu 1$ Maxima reverse transcriptase (Thermo), $0.25 \mu 1$ SUPERase in RNase inhibitor (Thermo) and $500 \mathrm{ng}$ of the total RNA sample. The reaction was carried out at $42^{\circ} \mathrm{C}$ for $30 \mathrm{~min}$ and by $85^{\circ} \mathrm{C}$ for $10 \mathrm{~min}$ in a Nexus Thermal Cycler (Eppendorf, Hamburg, Germany). Until further analysis, processed cDNA was stored at $-20^{\circ} \mathrm{C}$.

Relative expression levels of specific microRNAs were assessed by quantitative PCR applying a SYBR Green assay in a duplicate analysis. cDNA $(1 \mu \mathrm{l})$ with concentration of $5 \mathrm{ng} / \mu \mathrm{l}$ was mixed up with $9 \mu 1$ master mix containing $1 \mu 110 \mathrm{Xq}$ PCR buffer, $0.5 \mu 15 \mathrm{mM}$ dNTPs (Jena Bioscience), $0.5 \mu \mathrm{l}$ miRNA specific qPCR primer (Biomers), $0.5 \mu \mathrm{l}$ SYBR Green (Roche Diagnostics GmbH, Mannheim Germany), $0.05 \mu 1$ 
Table I. Tumor-biological relevance of pre-selected miRNA types.

\begin{tabular}{|c|c|c|c|}
\hline Pre-selected miR & Putative target & Reported function & References \\
\hline Let-7 & $\mathrm{BAX}$ & $\begin{array}{l}\text { Enhanced survival and } \\
\text { proliferation of cancer } \\
\text { cells (promoting EC) }\end{array}$ & Zhang et al (70) \\
\hline Let-7a & Aurora B & Inhibition of EC growth & Liu et al (57) \\
\hline Let-7b & $\begin{array}{l}\text { High mobility group } \\
\text { AT-hook } 2\end{array}$ & $\begin{array}{l}\text { Inhibition of aggressive } \\
\text { phenotypes }\end{array}$ & Romero-Perez et al (64) \\
\hline Let-7d & $\begin{array}{l}\text { LIN28, C-MYC, K-RAS, } \\
\text { HMGA2 and IMP-1 }\end{array}$ & $\begin{array}{l}\text { Tumor suppressor or } \\
\text { oncogene }\end{array}$ & Kolenda et al (54) \\
\hline Let-7i & $\begin{array}{l}\text { RAS, HMGA2, c-Myc, CDC25A, } \\
\text { CDK6 and cyclin D2 }\end{array}$ & Tumor suppressor & Yang et al (94) \\
\hline miR-10a & $\begin{array}{l}\text { USF2, HOXA1, HOXD10, } \\
\text { HOXB1, HOXB3, RB1CC1 }\end{array}$ & $\begin{array}{l}\text { Invasion, metastasis } \\
\text { (promoting EC) }\end{array}$ & Dai et al (50) \\
\hline $\operatorname{miR}-10 b$ & TBX5m DYRK1A, PTEN & $\begin{array}{l}\text { Oncomir, Migration, } \\
\text { invasion, proliferation }\end{array}$ & Kim et al (53) \\
\hline $\operatorname{miR}-15 a$ & Bck, MCL1, CCND1, WNT3 & Tumor suppressor & Aqeilan et al, Bonci et al $(46,47)$ \\
\hline $\operatorname{miR}-15 b$ & VEGF, CCND1, CCNE1 & $\begin{array}{l}\text { Tumor suppressor, } \\
\text { antiangiogenic }\end{array}$ & Zhao et al (71) \\
\hline miR-17 & VEGF-A, NOR-1, GALNT3 & Antiangiogenic & $\begin{array}{l}\text { Doebele } \text { et al, Hua } \text { et al, Lu } \text { et al, } \\
\text { Ramon et al }(41,51,63,95)\end{array}$ \\
\hline $\operatorname{miR}-19 b$ & PTEN, TGF $\beta$ & $\begin{array}{l}\text { Oncogene component } \\
\text { of mir-17-92-Cluster }\end{array}$ & $\begin{array}{l}\text { Doebele } \text { et al, Lu } \text { et al, } \\
\text { Ramon et al, } \\
\text { Fuziwara } \text { et al }(51,63,73,95)\end{array}$ \\
\hline miR-20a & VEGF-A & $\begin{array}{l}\text { Reduces angiogenesis } \\
\text { in EC }\end{array}$ & $\begin{array}{l}\text { Doebele et al, Lu et al, } \\
\text { Ramon et al }(51,63,95)\end{array}$ \\
\hline miR-20b & MMP-2 & Tumor suppressor & Park et al (59) \\
\hline $\operatorname{miR}-21$ & $\begin{array}{l}\text { Maspin, Pdcd4, } \\
\text { PTEN }\end{array}$ & $\begin{array}{l}\text { Tumorigenesis } \\
\text { Cell proliferation } \\
\text { (promoting EC) }\end{array}$ & Qin et al, Torres et al $(30,62)$ \\
\hline $\operatorname{miR}-22$ & Cyclin D1, MMP2, MM9 Er $\alpha$ & Tumor suppressor & Li et al, Wang et al $(56,69)$ \\
\hline miR-26a-1 & $\begin{array}{l}\text { CCNE1, ER } \alpha, \text { FGF9, } \\
\text { MTDH, EZH2, MCL-1 }\end{array}$ & $\begin{array}{l}\text { Antiproliferation, } \\
\text { proapoptotic, } \\
\text { metastasis inhibition, } \\
\text { growth inhibition }\end{array}$ & Chen et al (49) \\
\hline $\operatorname{miR}-27 \mathrm{a}$ & $\begin{array}{l}\text { FOXO1 } \\
\text { BAX }\end{array}$ & $\begin{array}{l}\text { Myometrial invasion } \\
\text { Inhibition of apoptosis, } \\
\text { increased survival of cancer } \\
\text { cells (promoting EC) }\end{array}$ & $\begin{array}{l}\text { Zhang et al, Mozos et al, } \\
\text { Myatt et al }(70,22,23)\end{array}$ \\
\hline $\operatorname{miR}-29 c$ & SPARCS (in EC) PI3K, CD42 & Tumor suppressor & Castilla et al, Park et al $(24,25)$ \\
\hline $\operatorname{miR}-30 b$ & SIX1 & Inhibits migration and invasion & Zhao et al (72) \\
\hline miR-92a & PTEN/PI3K/Akt/mTOR & $\begin{array}{l}\text { Member of miR-17-92 } \\
\text { cluster, promotes } \\
\text { carcinogenesis } \\
\text { in endometrial } \\
\text { epithelium, oncogene }\end{array}$ & Torres et al (67) \\
\hline $\operatorname{miR}-125 b$ & TP53INP1 & $\begin{array}{l}\text { Proliferation and migration } \\
\text { of cancer cells } \\
\text { (promoting EC) } \\
\text { Inhibition of cancer } \\
\text { cell invasion } \\
\text { (protecting against EC) }\end{array}$ & Jiang et al, Shang et al $(28,29)$ \\
\hline miR-128-1 & BMI1, E2F3 & Tumor suppressor & Shan et al (65) \\
\hline miR-135b & $\begin{array}{l}\text { VEGF A, HIF1 A, } \\
\text { HIFAN }\end{array}$ & $\begin{array}{l}\text { Tumor promoting } \\
\text { Upregulated in EC }\end{array}$ & Tsukamoto et al (68) \\
\hline
\end{tabular}


Table I. Continued.

\begin{tabular}{|c|c|c|c|}
\hline Pre-selected miR & Putative target & Reported function & References \\
\hline \multirow[t]{10}{*}{ miR-200c } & TIMP2 & Promoting EC: & Li et al, Park et al, \\
\hline & BRD7 & Metastasis of cancer & Snowdon et al $(32,33,34)$ \\
\hline & ZEBs, VEGF-A, FLT1, & cells & \\
\hline & IKK $\beta$, KLF9, FBLN5 & $\begin{array}{l}\text { Induction of cell survival } \\
\text { and proliferation }\end{array}$ & \\
\hline & & Reduction of apoptosis & \\
\hline & & Transition into cancerous states & \\
\hline & & Protective: & \\
\hline & FN1, MSN, NTRK2, & Downregulation & \\
\hline & LEPR, ARHGAP19 & promotes EMT phenotype & \\
\hline & & and aggressive behavior of cells & \\
\hline $\operatorname{miR}-222$ & c-kit CD117, PBX3 & Antiangiogenic activity & $\begin{array}{l}\text { Ramon et al, Poliseno et al, } \\
\text { Yanokura et al }(14,35,36)\end{array}$ \\
\hline
\end{tabular}

Table II. Molecular classification of investigated endometrial cancer cell lines.

\begin{tabular}{lcclc}
\hline Cell line & Classification & Immunoprofile & Primary tumor & Origin \\
\hline Ishikawa & Type I & $\mathrm{ER}^{+}, \mathrm{PR}^{+}$, & Endometrial adenocarcinoma & Uterus \\
EFE-184 & Type I & $\mathrm{ER}^{+}, \mathrm{PR}^{-}$ & Endometrium carcinoma & Ascitic fluid \\
AN3-CA & Type II & $\mathrm{ER}^{-}, \mathrm{PR}^{+}$ & Endometrial adenocarcinoma & Lymph node metastasis \\
\hline
\end{tabular}

ER, estrogen receptor; PR, progesterone receptor.

HotStart Taq (Jena Bioscience) and 6.54 $\mu$ l nuclease-free water (Analytic Jena). Primers consisted of a specific primer pair for each miRNA type and for the housekeeping genes.

Quantitative PCRs were performed on a LightCycler96 (Roche Diagnostics $\mathrm{GmbH}$ ) at $95^{\circ} \mathrm{C}$ for $2 \mathrm{~min}$, followed by 40 cycles at $95^{\circ} \mathrm{C}$, for $5 \mathrm{sec}$ and for $30 \mathrm{sec}$ at $60^{\circ} \mathrm{C}$.

Data were analyzed in Microsoft Excel using $\Delta \mathrm{Ct}$ method based on reference value (geometric mean of housekeeping genes, RNU48, miR-26b, miR-16 and miR-103 defined via 'BestKeeper' software tool (77) to determine single microRNA expression levels.

Pre-selection of miRNA specimen. A comprehensive survey was performed applying Pubmed interface for original research (http://www.ncbi.nlm.nih.gov/) and the miRTarBase platform (http://mirtarbase.mbc.nctu.edu.tw/) (78), specific miRNA information registry, to determine potential studyrelevant miRNA types. These sources were screened for relevant specimen in regard to 'endometrial cancer', typical endometrial cancer target genes and pathways as well as literature. A methodological pre-screening of $>40$ miRNA types was performed, which was based on the acquired information on potential miRNA candidates, to evaluate the experimental in vitro setting focusing on secreted miRNA specimen in cell culture media. The pre-set of miRNAs was filtered to collocate the final set of miRNAs which were reliably detectable in culture media. The hereby identified miRNA types and their functional implications are summarized in Table I.
Statistical analysis. Observed miRNA expression levels were graphically visualized in box plots, showing median and quartiles in cell lines Ishikawa, EFE-184 and AN3-CA under hypoxia, acidosis and normoxic conditions. The influence of treatment on miRNA expression levels of the different BC cell lines was investigated using a linear model with factor treatment (hypoxia and acidosis compared to normoxic conditions) and cell line, including an interaction term.

\section{Results}

In the present study we investigated the regulatory effect of hypoxia and acidosis on the expression levels of 24 different EC associated microRNA types (let-7a, let-7b, let-7d, let-7i, miR-10a, -10b, -15a, -15b, -17, -19b, -20a, -20b, -21, -22, -26-1, $27 \mathrm{a},-29 \mathrm{c},-30 \mathrm{~b},-92 \mathrm{a},-125 \mathrm{~b},-128-1,-135 \mathrm{~b},-200 \mathrm{c},-222)$ that are actively secreted into the tissue culture supernatant by EC cells. The characteristics of the investigated EC cell lines Ishikawa, EFE-184 and AN3-CA are summarized in Table II.

All 24 examined microRNAs were stably detectable in the supernatants of all three in vitro models. In order to examine potential regulatory effects triggered by typical microenvironmental alterations occurring in solid tumors during tumor growth, progression and metastasis on miRNA expression (79-82) hypoxia and acidosis were induced in the three cell lines. Expression levels of all EC associated miRNA types were determined under normoxic, hypoxic and acidotic conditions as mean $\Delta \mathrm{Ct}$ values of the distinct miRNA type 


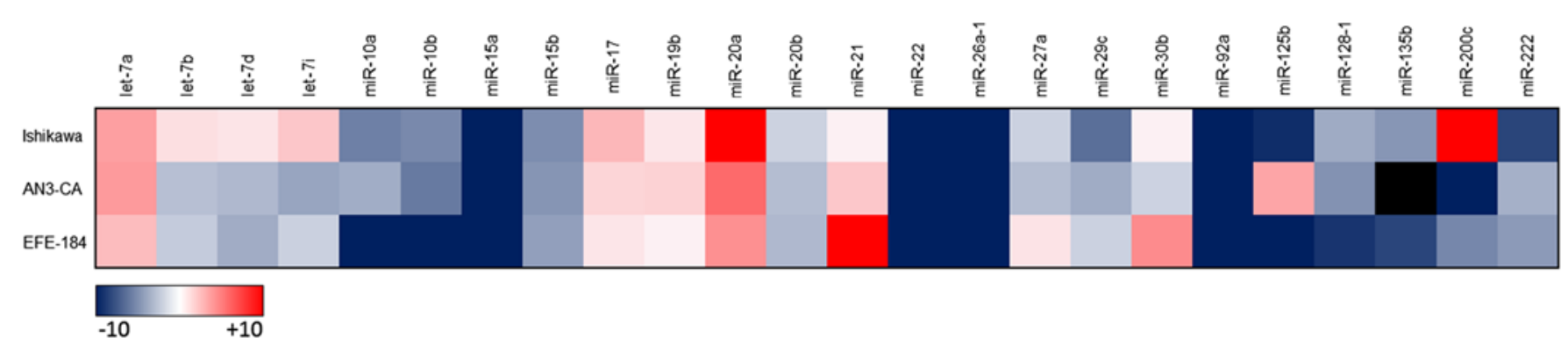

Figure 1. Expression profiles of secreted miRNAs in Ishikawa, EFE-184 and AN3-CA cells under normoxic (control) conditions. miRNA-expressions were determined in triplicates by real-time quantitative PCR and calculated using $\Delta \mathrm{Ct}$ method based on reference value (geometric mean of housekeeping genes, RNU48, miR-26b, miR-16 and miR-103) to determine single microRNA's expression levels.

Table III. Two-way analysis of variance for levels of secreted miR-15a under control, acidotic and hypoxic conditions in three different endometrial cancer cell lines.

\begin{tabular}{lcccc}
\hline & Estimate & Standard error & $95 \%$ CI & p-value \\
\hline Intercept & 0.047 & 0.007 & $0.034,0.060$ & 0.000 \\
Control & & & & \\
EFE-184 & -0.033 & 0.009 & $-0.052,-0.015$ & 0.002 \\
Ishikawa & 0.023 & 0.009 & $-0.005,0.032$ & 0.174 \\
Acidosis & & & & \\
AN3-CA & -0.007 & 0.009 & $-0.025,0.012$ & 0.489 \\
EFE-184 & 0.000 & 0.009 & $-0.018,0.018$ & 1.000 \\
Ishikawa & -0.007 & 0.009 & $-0.025,0.012$ & 0.489 \\
Hypoxia & & & & \\
AN3-CA & 0.000 & 0.009 & $-0.018,0.018$ & 1.000 \\
EFE-184 & 0.003 & 0.009 & $-0.015,0.022$ & 0.728 \\
Ishikawa & -0.020 & 0.009 & $-0.038,-0.002$ & 0.048 \\
\hline
\end{tabular}

Intercept is calculated on basis of AN3-CA control.

normalized against the geometric mean of the four housekeepers RNU48, miR-16, miR-26b and miR-103.

Under standard culture conditions each of the EC cell lines displayed a unique miRNA expression profile (Fig. 1). In response to hypoxia and acidosis, singular marked alterations in secreted miRNA expression levels were identified predominantly in Ishikawa cells.

Hypoxia triggered regulatory effects on the expression levels of miR-15a, miR-20a, miR-20b, miR-21 and miR-128-1. In Ishikawa cells, multivariable regression analysis identified a significant hypoxia-dependent downregulation of miR-15a, miR-20a, miR-20b and miR-128-1 expression. In detail, the expression level of miR-15a was decreased by a mean value of 0.020 (CI: $-0.038--0.002$; p=0.048) (Table III, Fig. 2), of miR-20a by 3.577 (CI: $-6.663--0.491 ; \mathrm{p}=0.036$ ) (Table IV, Fig. 2), miR-20b by $0.340(-0.544--0.136 ; \mathrm{p}=0.004)$ (Table $\mathrm{V}$, Fig. 2) and of miR-128-1 by $0.073(-0.136--0.011 ; p=0.034)$ (Table VI, Fig. 2). In EFE-184 and AN3-CA cells a comparable hypoxia-driven downregulatory effect on miRNA expression could not be detected. In EFE-184 cells a hypoxiainduced upregulation of miR-21 expression was observed.
Table IV. Two-way analysis of variance for levels of secreted miR-20a under control, acidotic and hypoxic conditions in three different endometrial cancer cell lines.

\begin{tabular}{lcccc}
\hline & Estimate & Standard error & $95 \%$ CI & p-value \\
\hline Intercept & 6.573 & 1.113 & $4.391,8.756$ & 0.000 \\
Control & & & & \\
EFE-184 & -1.657 & 1.575 & $-4.743,1.429$ & 0.307 \\
Ishikawa & 5.797 & 1.575 & $2.711,8.883$ & 0.002 \\
Acidosis & & & & \\
AN3-CA & -1.453 & 1.575 & $-4.539,1.633$ & 0.368 \\
EFE-184 & -0.660 & 1.575 & $-3.746,2.426$ & 0.680 \\
Ishikawa & -1.993 & 1.575 & $-5.079,1.093$ & 0.222 \\
Hypoxia & & & & \\
AN3-CA & -0.177 & 1.575 & $-3.263,2.909$ & 0.912 \\
EFE-184 & 0.007 & 1.575 & $-3.079,3.093$ & 0.997 \\
Ishikawa & -3.577 & 1.575 & $-6.663,-0.491$ & 0.036 \\
\hline
\end{tabular}

Intercept is calculated on basis of AN3-CA control.

The expression levels of secreted miR-21 levels in hypoxiaconditioned EFE-184 cells were increased by a mean value of 2.103 (CI: 0.300 - 3.907; p=0.035) (Table VII, Fig. 2). A hypoxia-dependent upregulatory effect on miRNA expression of AN3-CA and Ishikawa cells was not observed.

In response to acidosis, single marked alterations in secreted expression for let-7a, miR-22 and miR-125b were observed. In Ishikawa cells, $\Delta \mathrm{Ct}$ expression levels of let-7a were increased by a mean value of $1.980(-0.442-3.518 ; \mathrm{p}=0.021)$ (Table VIII, Fig. 3) and $\Delta \mathrm{Ct}$ expression levels of miR-22 were decreased by a mean value of $0.023(-0.044--0.003 ; p=0.040)$ (Table IX, Fig. 3). In AN3-CA cells a specific acidosis-dependent upregulation was observed for miR-125b. In detail, a mean increase of secreted miR-125b $\Delta$ Ct level by 1.007 (CI: 0.512 - 1.501; $\mathrm{p}=0.001$ ) became evident (Table X, Fig. 3). No significant acidosis-dependent miRNA expression level alterations were detected in EFE-184 cells.

No marked hypoxia- or acidosis-driven alterations in expression levels of let-7b, let-7d, let-7i, miR-10a, $-10 b,-15 b$, $-17,-19 b,-26-1,27 a,-29 c,-30 b,-92 a,-135 b,-200 c$ and 222 were observed in the investigated EC cell lines (data not shown). 

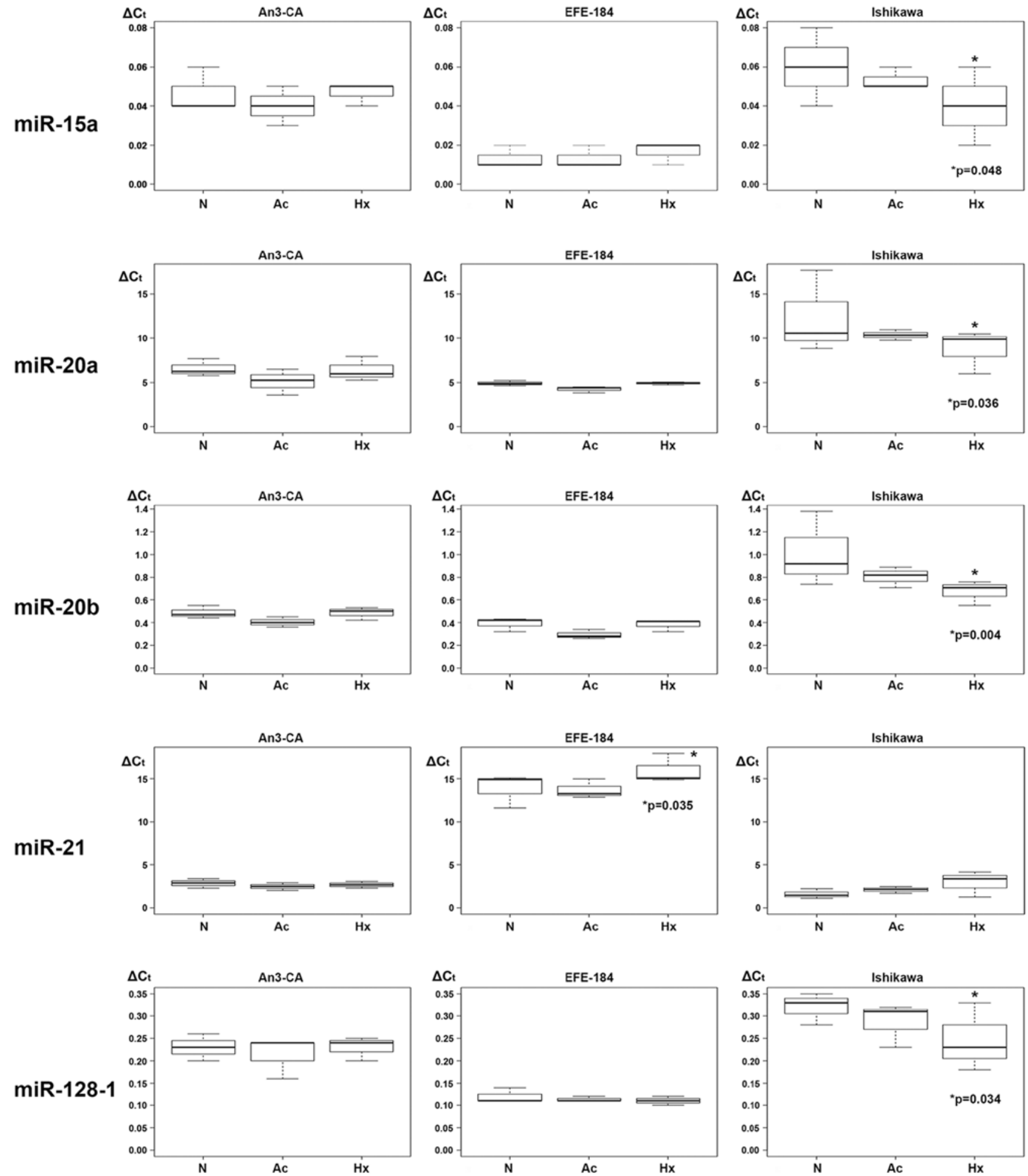

Figure 2. Box plot diagram of expression levels of significantly altered secreted miRNAs in response to hypoxia. Expression levels of secreted miR-15a, miR20a, miR-20b, miR-21 and miR-128-1 in endometrial cancer cell lines are displayed under varying treatment conditions. Levels of secreted miRNA expression were determined in AN3-CA, EFE-184 and Ishikawa cells under control conditions (N), extracellular acidosis (Ac) and hypoxia (Hx). Box plots demonstrate median (thick black line), lower and upper quantile range (box lines), and standard deviation range (dashed lines bounded by horizontal lines). Significant expression level alterations ( $\mathrm{p} \mathrm{p} \leq 0.05)$ of control conditions versus treatment options. Based on triplicate experiments, real-time quantitative PCR.

\section{Discussion}

Recent and ongoing studies account for a continually growing number of miRNA types with regulatory influence on EC tumorigenesis. While some of these miRNAs play an important role as tumor suppressors, expression of others is associated with promotion of tumor growth, invasion and metastasis (oncogenic miRNAs, oncomiRs). In the present study, we analyzed the expression of a panel of secreted EC associated microRNAs with impact on angiogenesis, proliferation, invasion, migration and metastasis including let-7a, let-7b, let-7d, let-7i, miR-10a, -10b, -15a, -15b, -17, -19b, -20a, -20b, -21, -22, 

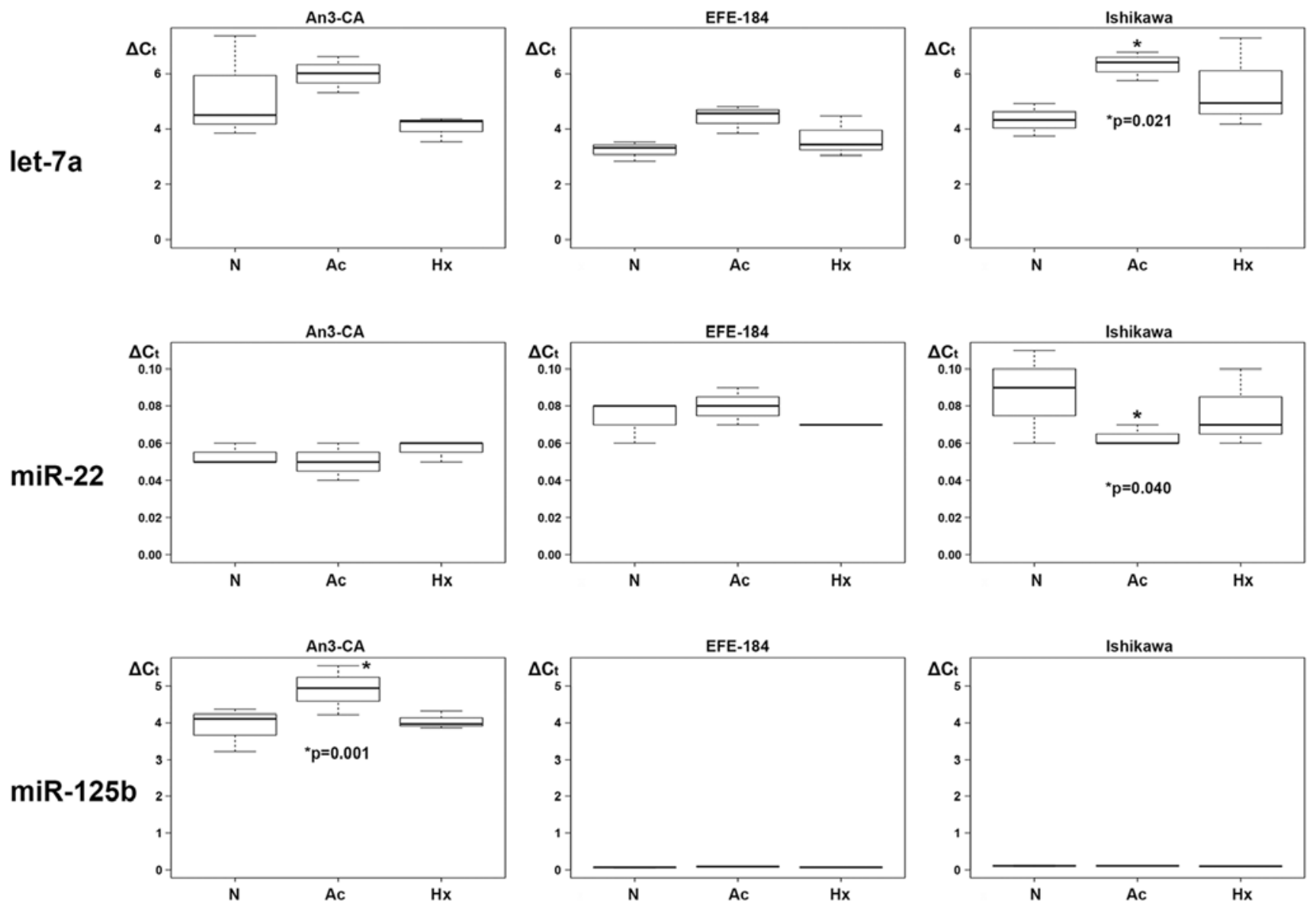

Figure 3. Box plot diagram of expression levels of significantly altered secreted miRNAs in response to acidosis. Expression levels of secreted let-7a, miR22 and miR-125b in endometrial cancer cell lines are displayed under varying treatment conditions. Levels of secreted miRNA expression were determined in AN3-CA, EFE-184 and Ishikawa cells under control conditions (N), extracellular acidosis (Ac) and hypoxia (Hx). Box plots demonstrate median (thick black line), lower and upper quantile range (box lines), and standard deviation range (dashed lines bounded by horizontal lines). Significant expression level alterations $\left({ }^{*} \mathrm{p} \leq 0.05\right)$ of control conditions versus treatment options. Based on triplicate experiments, real-time quantitative PCR.

$-26.1,27 \mathrm{a},-29 \mathrm{c},-30 \mathrm{~b},-92 \mathrm{a},-125 \mathrm{~b},-128-1,-135 \mathrm{~b},-200 \mathrm{c},-222$ We were able to reliably detect all 24 secreted miRNA types in the supernatants of the three analyzed EC cell lines. Based on these EC in vitro models a quantitative analysis of secreted miRNA expression levels was employed to detect potential alterations under the typical tumor biological epiphenomena hypoxia and acidosis.

Our data clearly account for a hypoxia- and acidosisdependent regulatory effect in the expression levels of eight specific secreted miRNAs (let-7a, miR-15a, miR-20a, miR-20b, miR-21, miR-22, miR-125b and miR-128-1) among the investigated miRNA types. The observed alterations in miRNA expression levels were not consistent in all three EC cell lines. Significant miRNA deregulation due to hypoxia or acidosis was predominantly observed in Ishikawa cells. In EFE-184 and AN3-CA cells a regulatory effect was observed solely for one specific miRNA type. Hypoxia resulted in downregulation of miR-15a, miR-20a, miR-20b and miR-128-1 in Ishikawa cells and upregulation of miR-21 in EFE-184 cells.

miR-15a is considered to trigger tumor suppressive effects by inhibiting several target oncogenes, like BCL2, MCL1, CCND1 and WNT3A $(46,47)$. Thus, cells react with diminished proliferation, an increase in apoptosis rates and suppressed tumorigenicity both in vitro and in vivo. In chronic lymphocytic lymphoma (CLL), prostate carcinomas and pitu- itary adenomas, downregulation of miR-15a expression has been observed (46). In the present study, hypoxic conditions resulted in decreased miR15a expression in Ishikawa cells. This finding accounts for a reduced inhibitory signaling function on angiogenesis in type I EC cells under hypoxic stress and is supported by the results of Hua et al reported that in a tumor cell model VEGF expression is repressed, besides others, by miRNAs (miR15b, miR16) from the miR15-16 clustered family (41).

The miR-17-92 cluster, which contains six mature miRNAs (miR-17, -18a, -19a, -19b, -20a and -92a), conducts a complex role in angiogenetic signaling cascades (65) In the present analysis, we evaluated four specific miRNAs of this cluster: miR-17, miR-19b, miR-20a and miR-92a. Anti-angiogenetic activity of miR-20a by targeting VEGF-A has been reported $(41,65)$. Inconsistent results have been reported for the role of miR-17 so far. While some investigatory approaches hypothesize an anti-angiogenetic activity $(41,51)$, other studies account for either pro-angiogenetic activity $(83,84)$ or no association with VEGF-A expression (65). Our data identified a significant hypoxia-driven expression reduction of miR20a in Ishikawa cells. For miR-17, miR-19b and miR-92a no significant changes in expression levels were observed. Our results are in line with the findings of Ramon et al and support the proposition that miR-20a, but not miR-17 and miR-19b, 
Table V. Two-way analysis of variance for levels of secreted miR-20b under control, acidotic and hypoxic conditions in three different endometrial cancer cell lines.

\begin{tabular}{lcccc}
\hline & Estimate & Standard error & $95 \%$ CI & p-value \\
\hline Intercept & 0.487 & 0.073 & $0.343,0.631$ & 0.000 \\
Control & & & & \\
EFE-184 & -0.097 & 0.104 & $-0.300,0.107$ & 0.365 \\
Ishikawa & 0.527 & 0.104 & $0.323,0.730$ & 0.000 \\
Acidosis & & & & \\
AN3-CA & -0.083 & 0.104 & $-0.287,0.120$ & 0.433 \\
EFE-184 & -0.097 & 0.104 & $-0.300,0.107$ & 0.365 \\
Ishikawa & -0.207 & 0.104 & $-0.410,-0.003$ & 0.062 \\
Hypoxia & & & & \\
AN3-CA & -0.003 & 0.104 & $-0.207,0.200$ & 0.975 \\
EFE-184 & -0.010 & 0.104 & $-0.214,0.194$ & 0.924 \\
Ishikawa & -0.340 & 0.104 & $-0.544,-0.136$ & 0.004 \\
\hline
\end{tabular}

Intercept is calculated on basis of AN3-CA control.

Table VI. Two-way analysis of variance for levels of secreted miR-128-1 under control, acidotic and hypoxic conditions in three different endometrial cancer cell lines.

\begin{tabular}{ccccc}
\hline & Estimate & Standard error & $95 \%$ CI & p-value \\
\hline Intercept & 0.230 & 0.023 & $0.186,0.274$ & 0.000 \\
Control & & & & \\
EFE-184 & -0.110 & 0.032 & $-0.173,-0.047$ & 0.003 \\
Ishikawa & 0.090 & 0.032 & $0.027,0.153$ & 0.011 \\
Acidosis & & & & \\
AN3-CA & -0.017 & 0.032 & $-0.079,0.046$ & 0.608 \\
EFE-184 & -0.007 & 0.032 & $-0.069,0.056$ & 0.837 \\
Ishikawa & -0.033 & 0.032 & $-0.096,0.029$ & 0.310 \\
Hypoxia & & & & \\
AN3-CA & 0.000 & 0.032 & $-0.063,0.063$ & 1.000 \\
EFE-184 & -0.010 & 0.032 & $-0.073,0.053$ & 0.757 \\
Ishikawa & -0.073 & 0.032 & $-0.136,-0.011$ & 0.034 \\
\hline
\end{tabular}

Intercept is calculated on basis of AN3-CA control.

displays an anti-angiogenetic activity, which is reduced under hypoxic stress conditions in EC tumor cells (65).

MiR-20b has a tumor suppressive function by impeding MMP-2 expression leading to cell cycle arrest (61) as well as regulative function on oxygen balance of cells. Lei et al described that tumor cells are able to adapt to alterations of oxygen concentration by miR-20b triggered regulation of HIF- $1 \alpha$ and VEGF. In their study inhibition of miR-20b increased protein levels of VEGF and HIF-1 $\alpha$ in normoxic tumor cells, an increase of miR-20b expression in hypoxic tumor cells resulted in reduced protein levels of VEGF and HIF-1 $\alpha$ (85). Park et al showed that miR-20b expression was
Table VII. Two-way analysis of variance for levels of secreted miR-21 under control, acidotic and hypoxic conditions in three different endometrial cancer cell lines.

\begin{tabular}{lcccc}
\hline & Estimate & Standard error & $95 \%$ CI & p-value \\
\hline Intercept & 2.853 & 0.651 & 1.5784 .128 & 0.000 \\
Control & & & & \\
EFE-184 & 11.013 & 0.920 & 9.21012 .817 & 0.000 \\
Ishikawa & -1.253 & 0.920 & -3.0570 .550 & 0.190 \\
Acidosis & & & & \\
AN3-CA & -0.377 & 0.920 & -2.1801 .427 & 0.687 \\
EFE-184 & -0.167 & 0.920 & -1.9701 .637 & 0.858 \\
Ishikawa & 0.510 & 0.920 & -1.2932 .313 & 0.586 \\
Hypoxia & & & & \\
AN3-CA & -0.177 & 0.920 & -1.9801 .627 & 0.850 \\
EFE-184 & 2.103 & 0.920 & 0.3003 .907 & 0.035 \\
Ishikawa & 1.330 & 0.920 & -0.4733 .133 & 0.165 \\
\hline
\end{tabular}

Intercept is calculated on basis of AN3-CA control.

Table VIII. Two-way analysis of variance for levels of secreted let7a under control, acidotic and hypoxic conditions in three different endometrial cancer cell lines.

\begin{tabular}{ccccc}
\hline & Estimate & Standard error & $95 \%$ CI & p-value \\
\hline Intercept & 5.243 & 0.555 & $4.156,6.331$ & 0.000 \\
Control & & & & \\
EFE-184 & -2.020 & 0.785 & $-3.558,-0.482$ & 0.019 \\
Ishikawa & -0.917 & 0.785 & $-2.454,0.621$ & 0.258 \\
Acidosis & & & & \\
AN3-CA & -0.737 & 0.785 & $-0.801,2.274$ & 0.360 \\
EFE-184 & 1.180 & 0.785 & $-0.358,2.718$ & 0.150 \\
Ishikawa & 1.980 & 0.785 & $0.442,3.518$ & 0.021 \\
Hypoxia & & & & \\
AN3-CA & -1.183 & 0.785 & $-2.721,0.354$ & 0.149 \\
EFE-184 & 0.427 & 0.785 & $-1.111,1.964$ & 0.593 \\
Ishikawa & 1.140 & 0.785 & $-0.398,2.678$ & 0.163 \\
\hline
\end{tabular}

Intercept is calculated on basis of AN3-CA control.

downregulated in bladder cancer and an upregulation of this miRNA type lead to inhibition of proliferation, migration and invasion (61). In gastric cancer, downregulated miR-20b expression was associated with hypoxia-induced chemoresistance. In the present study we observed reduced miR-20b expression levels in Ishikawa cells under hypoxic conditions. These data are in line with aforementioned reports of Lei et al as well as of Danza et al in gastric cancer $(85,86)$.

Under hypoxic conditions expression levels of miR-128-1 were also found reduced in Ishikawa cells. miR-128-1 is supposed to act as a tumor suppressor inhibiting tumor cell proliferation, invasion and self-renewal by direct targeting 
Table IX. Two-way analysis of variance for levels of secreted miR-22 under control, acidotic and hypoxic conditions in three different endometrial cancer cell lines.

\begin{tabular}{lcccc}
\hline & Estimate & Standard error & $95 \%$ CI & p-value \\
\hline Intercept & 0.053 & 0.007 & $0.039,0.068$ & 0.000 \\
Control & & & & \\
EFE-184 & 0.020 & 0.011 & $-0.001,0.041$ & 0.074 \\
Ishikawa & 0.033 & 0.011 & $0.013,0.054$ & 0.005 \\
Acidosis & & & & \\
AN3-CA & -0.003 & 0.011 & $-0.024,0.017$ & 0.755 \\
EFE-184 & 0.007 & 0.011 & $-0.014,0.027$ & 0.535 \\
Ishikawa & -0.023 & 0.011 & $-0.044,-0.003$ & 0.040 \\
Hypoxia & & & & \\
AN3-CA & 0.003 & 0.011 & $-0.017,0.024$ & 0.755 \\
EFE-184 & -0.003 & 0.011 & $-0.024,0.017$ & 0.755 \\
Ishikawa & -0.010 & 0.011 & $-0.031,0.011$ & 0.355 \\
\hline
\end{tabular}

Intercept is calculated on basis of AN3-CA control.

Table X. Two-way analysis of variance for levels of secreted miR-125b under control, acidotic and hypoxic conditions in three different endometrial cancer cell lines.

\begin{tabular}{lcccc}
\hline & Estimate & Standard error & $95 \%$ CI & p-value \\
\hline Intercept & 3.893 & 0.178 & $3.544,4.243$ & 0.000 \\
Control & & & & \\
EFE-184 & -3.830 & 0.252 & $-4.324,-3.336$ & 0.000 \\
Ishikawa & -3.783 & 0.252 & $-4.278,-3.289$ & 0.000 \\
Acidosis & & & & \\
AN3-CA & 1.007 & 0.252 & $0.512,1.501$ & 0.001 \\
EFE-184 & 0.027 & 0.252 & $-0.468,0.521$ & 0.917 \\
Ishikawa & 0.000 & 0.252 & $-0.494,0.494$ & 1.000 \\
Hypoxia & & & & \\
AN3-CA & 0.153 & 0.252 & $-0.341,0.648$ & 0.551 \\
EFE-184 & 0.003 & 0.252 & $-0.491,0.498$ & 0.990 \\
Ishikawa & -0.010 & 0.252 & $-0.504,0.484$ & 0.969 \\
\hline
\end{tabular}

Intercept is calculated on basis of AN3-CA control.

of BMI1 and E2F3 in glioblastomas (67). Furthermore, it has been associated with inhibition of the mTOR signaling pathway in glioblastomas. Decreased miR-128-1 expression levels in glioblastomas could be strongly associated with poor survival (87). The observed reduced expression levels of miR-128-1 in Ishikawa cells under hypoxic conditions may also account for a regulative function of miR-128-1 in EC.

MiR-21 expression levels were increased in EFE-184 cells under oxygen deprivation. This observation is in line with previous studies showing that miR-21 is an active participant in EEC malignant transformation by abrogating the regulatory function of PTEN, which has been found to be upregulated in
EEC $(24,64)$. Furthermore, a regulating role of miR-21 on the expression of the tumor suppressor gene Pdcd4 (programmed cell death-4) and Maspin, which is strongly associated with angiogenesis in EC, has been indicated (88). Whether Maspin acts as tumor suppressor or tumor promoter, seems to be complex and dependent on the tissue specific environment (89). In EC high Maspin expression has been associated with higher FIGO stage, lymph node involvement and the depth of myometrial invasion as well as poor prognosis (90). Additionally a correlation between high miR-21 expression and increased Maspin expression has been reported in EC (89).

Acidosis resulted in divergent miRNA expression patterns in the analyzed EC cell lines. While let-7a expression was found to be upregulated, miR-22 expression levels were downregulated under acidotic conditions in Ishikawa cells. Let-7a acts as tumor suppressor due to inhibition of EC growth by targeting and downregulating Aurora B $(1,21,24)$. In EC let-7a expression levels are usually downregulated (58). miR-22 exerts tumor suppressive functions by influencing Cyclin D1, MMP2, PTEN and others (71). Li et al reported an inhibitory function of miR-22 expression on proliferation and invasion in estrogen receptor $\alpha$-positive endometrial endometrioid carcinoma cells (57).

In AN3-CA cells miR-125b was significantly upregulated under acidotic conditions. These data are in line with previous findings showing an upregulated miR-125b expression in type II EC cells. Proliferation and migration of type II EC cancer cells was promoted by miR-125b in this study by targeting the tumor suppressor gene TP53INP1 (53).

In summary, our data clearly identify a hypoxia-dependent downregulation of secreted miRNAs with tumor suppressive and anti-angiogenetic function (miR-15a, miR-20a, miR-20b, miR-128-1) as well as upregulation of secreted miRNAs with tumor and angiogenesis promoting function (miR-21) in type I EC cell lines (Ishikawa, EFE-184). In contrast, in the analyzed type II EC cell line (AN3-CA) hypoxia did not show any significant impact on the expression pattern of the analyzed EC related miRNAs.

Acidosis triggered upregulation of the tumor promoting miRNA miR-125b in AN3-CA cells (type II EC). In Ishikawa cells (type I EC) the tumor promoting or tumor suppressive impact of acidosis is not clear yet since miRNAs with tumor suppressive function were found altered in divergent directions, both up- (let-7a) and down- (miR-22) regulated.

In conclusion, our current findings emphasize the functional importance of secreted miRNAs in the immediate response of EC cells to exogenic stress situations such as the typical tumor epiphenomena hypoxia and acidosis. Focusing on the specific potential of secreted, thus circulating miRNA molecules, that also conduct an inter-cellular (hormone-like) signaling function, alterations in expression levels not only influence intracellular gene expression and signaling cascades, but also transfer the induction of (tumor)biological cellular changes to adjacent cells $(91,92)$ Thus, the fate of whole tissue areas may undergo transformation in respect to metabolic pathways, cell cycle control and neo-angiogenesis, that support malignant progression. To rule out the possibility of in vitro/ in vivo differences of the analyzed secreted miRNA expression levels as well as to support the transferability of the observed results to in vivo settings, the data of the present in vitro study 
on EC cancer cell lines should be confirmed by corresponding in vivo analyses based on tumor tissue specimen and/or body fluids (e.g. blood, urine) of EC patients.

Continuous elucidation of miRNA functions augments the potential of these regulatory nucleic acid elements to either be implemented as useful biomarkers in disease/malignancy diagnosis, prognosis and therapy monitoring, as well as novel therapeutic targets ('AntagomiRs') in clinical cancer management $(1,21,93)$. The potential applicability of circulating miRNAs as non-invasive biomarkers for diagnosis (32) or as therapeutic targets $(94,95)$ in EC is currently subject of various studies. In this context this in vitro model may serve as initial step to elucidate the influence of microenvironmental changes on expression profiles of circulating microRNAs in EC.

\section{References}

1. Yanokura M, Banno K, Iida M, Irie H, Umene K, Masuda K, Kobayashi Y, Tominaga E and Aoki D: MicroRNAS in endometrial cancer: Recent advances and potential clinical applications. EXCLI J 14: 190-198, 2015.

2. Iorio MV, Visone R, Di Leva G, Donati V, Petrocca F, Casalini P, Taccioli C, Volinia S, Liu CG, Alder H, et al: MicroRNA signatures in human ovarian cancer. Cancer Res 67: 8699-8707, 2007.

3. Liz J and Esteller M: lncRNAs and microRNAs with a role in cancer development. Biochim Biophys Acta 1859: 169-176, 2016.

4. Lewis BP, Burge CB and Bartel DP: Conserved seed pairing, often flanked by adenosines, indicates that thousands of human genes are microRNA targets. Cell 120: 15-20, 2005.

5. Sandhu S and Garzon R: Potential applications of microRNAs in cancer diagnosis, prognosis, and treatment. Semin Oncol 38: 781-787, 2011.

6. Thorsen SB, Obad S, Jensen NF, Stenvang J and Kauppinen S: The therapeutic potential of microRNAs in cancer. Cancer J 18: 275-284, 2012.

7. Boren T, Xiong Y, Hakam A, Wenham R, Apte S, Wei Z, Kamath S, Chen DT, Dressman H and Lancaster JM: MicroRNAs and their target messenger RNAs associated with endometrial carcinogenesis. Gynecol Oncol 110: 206-215, 2008.

8. Le XF, Merchant O, Bast RC and Calin GA: The roles of microRNAs in the cancer invasion-metastasis cascade. Cancer Microenviron 3: 137-147, 2010.

9. Ratner ES, Tuck D, Richter C, Nallur S, Patel RM, Schultz V, Hui P, Schwartz PE, Rutherford TJ and Weidhaas JB: MicroRNA signatures differentiate uterine cancer tumor subtypes. Gynecol Oncol 118: 251-257, 2010.

10. Kosaka N, Iguchi $\mathrm{H}$ and Ochiya T: Circulating microRNA in body fluid: A new potential biomarker for cancer diagnosis and prognosis. Cancer Sci 101: 2087-2092, 2010.

11. Huang YK and Yu JC: Circulating microRNAs and long noncoding RNAs in gastric cancer diagnosis: An update and review. World J Gastroenterol 21: 9863-9886, 2015.

12. Kosaka $\mathrm{N}$ and Ochiya T: Unraveling the mystery of cancer by secretory microRNA: Horizontal microRNA transfer between living cells. Front Genet 2: 97, 2012.

13. Turchinovich A, Weiz L, Langheinz A and Burwinkel B: Characterization of extracellular circulating microRNA. Nucleic Acids Res 39: 7223-7233, 2011.

14. Arroyo JD, Chevillet JR, Kroh EM, Ruf IK, Pritchard CC, Gibson DF, Mitchell PS, Bennett CF, Pogosova-Agadjanyan EL, Stirewalt DL, et al: Argonaute2 complexes carry a population of circulating microRNAs independent of vesicles in human plasma. Proc Natl Acad Sci USA 108: 5003-5008, 2011.

15. Wang K, Zhang S, Weber J, Baxter D and Galas DJ: Export of microRNAs and microRNA-protective protein by mammalian cells. Nucleic Acids Res 38: 7248-7259, 2010.

16. Zhang J, Li S, Li L, Li M, Guo C, Yao J and Mi S: Exosome and exosomal microRNA: Trafficking, sorting, and function. Genomics Proteomics Bioinformatics 13: 17-24, 2015.

17. Siegel RL, Miller KD and Jemal A: Cancer statistics, 2016. CA Cancer J Clin 66: 7-30, 2016.

18. Sorosky JI: Endometrial cancer. Obstet Gynecol 120: 383-397, 2012.
19. Hecht JL and Mutter GL: Molecular and pathologic aspects of endometrial carcinogenesis. J Clin Oncol 24: 4783-4791, 2006.

20. Murali R, Soslow RA and Weigelt B: Classification of endometrial carcinoma: More than two types. Lancet Oncol 15: e268-e278, 2014.

21. Sianou A, Galyfos G, Moragianni D, Andromidas P, Kaparos G, Baka $S$ and Kouskouni $E$ : The role of microRNAs in the pathogenesis of endometrial cancer: A systematic review. Arch Gynecol Obstet 292: 271-282, 2015.

22. Chung TK, Lau TS, Cheung TH, Yim SF, Lo KW, Siu NS, Chan LK, Yu MY, Kwong J, Doran G, et al: Dysregulation of microRNA-204 mediates migration and invasion of endometrial cancer by regulating FOXC1. Int J Cancer 130: 1036-1045, 2012.

23. Devor EJ, Hovey AM, Goodheart MJ, Ramachandran S and Leslie KK: microRNA expression profiling of endometrial endometrioid adenocarcinomas and serous adenocarcinomas reveals profiles containing shared, unique and differentiating groups of microRNAs. Oncol Rep 26: 995-1002, 2011.

24. Kontomanolis EN and Koukourakis MI: MicroRNA: The Potential Regulator of Endometrial Carcinogenesis. MicroRNA 4: $18-25,2015$.

25. Myatt SS and Lam EW: The emerging roles of forkhead box (Fox) proteins in cancer. Nat Rev Cancer 7: 847-859, 2007.

26. Myatt SS, Wang J, Monteiro LJ, Christian M, Ho KK, Fusi L, Dina RE, Brosens JJ, Ghaem-Maghami S and Lam EW: Definition of microRNAs that repress expression of the tumor suppressor gene FOXO1 in endometrial cancer. Cancer Res 70: 367-377, 2010.

27. Hiroki E, Suzuki F, Akahira J, Nagase S, Ito K, Sugawara J, Miki Y, Suzuki T, Sasano H and Yaegashi N: MicroRNA-34b functions as a potential tumor suppressor in endometrial serous adenocarcinoma. Int J Cancer 131: E395-E404, 2012.

28. Park YA, Lee JW, Choi JJ, Jeon HK, Cho Y, Choi C, Kim TJ, Lee NW, Kim BG and Bae DS: The interactions between MicroRNA-200c and BRD7 in endometrial carcinoma. Gynecol Oncol 124: 125-133, 2012.

29. Snowdon J, Zhang X, Childs T, Tron VA and Feilotter H: The microRNA-200 family is upregulated in endometrial carcinoma. PLoS One 6: e22828, 2011.

30. Torres A, Torres K, Paszkowski T, Radej S, Staśkiewicz GJ, Ceccaroni M, Pesci A and Maciejewski R: Highly increased maspin expression corresponds with up-regulation of miR-21 in endometrial cancer: a preliminary report. Int J Gynecol Cancer 21: 8-14, 2011.

31. Chen X, Ba Y, Ma L, Cai X, Yin Y, Wang K, Guo J, Zhang Y, Chen J, Guo X, et al: Characterization of microRNAs in serum: A novel class of biomarkers for diagnosis of cancer and other diseases. Cell Res 18: 997-1006, 2008.

32. Jia W, Wu Y, Zhang Q, Gao G, Zhang C and Xiang Y: Identification of four serum microRNAs from a genome-wide serum microRNA expression profile as potential non-invasive biomarkers for endometrioid endometrial cancer. Oncol Lett 6: 261-267, 2013.

33. Blick C, Ramachandran A, McCormick R, Wigfield S, Cranston D, Catto J and Harris AL: Identification of a hypoxiaregulated miRNA signature in bladder cancer and a role for miR-145 in hypoxia-dependent apoptosis. Br J Cancer 113: 634-644, 2015.

34. Jung KO, Youn H, Lee CH, Kang KW and Chung JK: Visualization of exosome-mediated miR-210 transfer from hypoxic tumor cells. Oncotarget 8: 9899-9910, 2017.

35. Dai L, Lou W, Zhu J, Zhou X and Di W: MiR-199a inhibits the angiogenic potential of endometrial stromal cells under hypoxia by targeting HIF-1 $\alpha /$ VEGF pathway. Int J Clin Exp Pathol 8: 4735-4744, 2015.

36. Lin SC, Wang CC, Wu MH, Yang SH, Li YH and Tsai SJ: Hypoxia-induced microRNA-20a expression increases ERK phosphorylation and angiogenic gene expression in endometriotic stromal cells. J Clin Endocrinol Metab 97: E1515-E1523, 2012.

37. Xu TX, Zhao SZ, Dong M and Yu XR: Hypoxia responsive miR-210 promotes cell survival and autophagy of endometriotic cells in hypoxia. Eur Rev Med Pharmacol Sci 20: 399-406, 2016.

38. Harris AL: Hypoxia - a key regulatory factor in tumour growth. Nat Rev Cancer 2: 38-47, 2002.

39. Umezu T, Tadokoro H, Azuma K, Yoshizawa S, Ohyashiki K and Ohyashiki JH: Exosomal miR-135b shed from hypoxic multiple myeloma cells enhances angiogenesis by targeting factorinhibiting HIF-1. Blood 124: 3748-3757, 2014. 
40. Kulshreshtha R, Ferracin M, Wojcik SE, Garzon R, Alder H, Agosto-Perez FJ, Davuluri R, Liu CG, Croce CM, Negrini M, et al: A microRNA signature of hypoxia. Mol Cell Biol 27: 1859-1867, 2007

41. Hua Z, Lv Q, Ye W, Wong CK, Cai G, Gu D, Ji Y, Zhao C, Wang J, Yang BB, et al: MiRNA-directed regulation of VEGF and other angiogenic factors under hypoxia. PLoS One 1: e116, 2006.

42. Gatenby RA, Gawlinski ET, Gmitro AF, Kaylor B and Gillies RJ: Acid-mediated tumor invasion: A multidisciplinary study. Cancer Res 66: 5216-5223, 2006

43. Chiche J, Brahimi-Horn MC and Pouysségur J: Tumour hypoxia induces a metabolic shift causing acidosis: A common feature in cancer. J Cell Mol Med 14: 771-794, 2010.

44. Lardner A: The effects of extracellular $\mathrm{pH}$ on immune function. J Leukoc Biol 69: 522-530, 2001.

45. Bristow RG and Hill RP: Hypoxia and metabolism. Hypoxia, DNA repair and genetic instability. Nat Rev Cancer 8: 180-192, 2008.

46. Aqeilan RI, Calin GA and Croce CM: miR-15a and miR-16-1 in cancer: Discovery, function and future perspectives. Cell Death Differ 17: 215-220, 2010

47. Bonci D, Coppola V, Musumeci M, Addario A, Giuffrida R, Memeo L, D'Urso L, Pagliuca A, Biffoni M,Labbaye C, et al: The miR-15a-miR-16-1 cluster controls prostate cancer by targeting multiple oncogenic activities. Nat Med 14: 1271-1277, 2008.

48. Castilla MA, Moreno-Bueno G, Romero-Pérez L, Van De Vijver K, Biscuola M, López-García MÁ, Prat J, Matías-Guiu X, Cano A, Oliva E, et al: Micro-RNA signature of the epithelial-mesenchymal transition in endometrial carcinosarcoma. J Pathol 223: 72-80, 2011.

49. Chen J, Zhang K, Xu Y, Gao Y, Li C, Wang R and Chen L: The role of microRNA-26a in human cancer progression and clinical application. Tumour Biol 37: 7095-7108, 2016.

50. Dai Y, Xia W, Song T, Su X, Li J, Li S, Chen Y, Wang W, Ding H, Liu X, et al: MicroRNA-200b is overexpressed in endometrial adenocarcinomas and enhances MMP2 activity by downregulating TIMP2 in human endometrial cancer cell line HEC-1A cells. Nucleic Acid Ther 23: 29-34, 2013.

51. Doebele C, Bonauer A, Fischer A, Scholz A, Reiss Y, Urbich C, Hofmann WK, Zeiher AM and Dimmeler S: Members of the microRNA-17-92 cluster exhibit a cell-intrinsic antiangiogenic function in endothelial cells. Blood 115: 4944-4950, 2010.

52. Fuziwara CS and Kimura ET: Insights into regulation of the miR-17-92 cluster of miRNAs in cancer. Front Med (Lausanne) 2: 64,2015

53. Jiang F, Liu T, He Y, Yan Q, Chen X, Wang H and Wan X MiR-125b promotes proliferation and migration of type II endometrial carcinoma cells through targeting TP53INP1 tumor suppressor in vitro and in vivo. BMC Cancer 11: 425, 2011.

54. Kim J, Siverly AN, Chen D, Wang M, Yuan Y, Wang Y, Lee H, Zhang J, Muller WJ, Liang H, et al: Ablation of miR-10b suppresses oncogene-induced mammary tumorigenesis and metastasis and reactivates tumor-suppressive pathways. Cancer Res 76: 6424-6435, 2016

55. Kolenda T, Przybyła W, Teresiak A, Mackiewicz A and Lamperska KM: The mystery of let-7d - a small RNA with great power. Contemp Oncol (Pozn) 18: 293-301, 2014.

56. Li BL, Lu W, Lu C, Qu JJ, Yang TT, Yan Q and Wan XP: CpG island hypermethylation-associated silencing of microRNAs promotes human endometrial cancer. Cancer Cell Int 13: 44 2013.

57. Li S, Hu R, Wang C, Guo F, Li X and Wang S: miR-22 inhibits proliferation and invasion in estrogen receptor $\alpha$-positive endometrial endometrioid carcinomas cells. Mol Med Rep 9: 2393-2399, 2014.

58. Liu P, Qi M, Ma C, Lao G, Liu Y, Liu Y and Liu Y: Let7a inhibits the growth of endometrial carcinoma cells by targeting Aurora-B. FEBS Lett 587: 2523-2529, 2013.

59. Lu J, Zhang X, Zhang R and Ge Q: MicroRNA heterogeneity in endometrial cancer cell lines revealed by deep sequencing. Oncol Lett 10: 3457-3465, 2015 .

60. Mozos A, Catasús L, D'Angelo E, Serrano E, Espinosa I, Ferrer I, Pons C and Prat J: The FOXO1-miR27 tandem regulates myometrial invasion in endometrioid endometrial adenocarcinoma. Hum Pathol 45: 942-951, 2014.

61. Park SL, Cho TM, Won SY, Song JH, Noh DH, Kim WJ and Moon SK: MicroRNA-20b inhibits the proliferation, migration and invasion of bladder cancer EJ cells via the targeting of cell cycle regulation and Sp-1-mediated MMP-2 expression. Oncol Rep 34: 1605-1612, 2015
62. Park SY, Lee JH, Ha M, Nam JW and Kim VN: miR-29 miRNAs activate $\mathrm{p} 53$ by targeting $\mathrm{p} 85$ alpha and CDC42. Nat Struct Mol Biol 16: 23-29, 2009

63. Poliseno L, Tuccoli A, Mariani L, Evangelista M, Citti L, Woods K, Mercatanti A, Hammond $S$ and Rainaldi G: MicroRNAs modulate the angiogenic properties of HUVECs. Blood 108: 3068-3071, 2006.

64. Qin X, Yan L, Zhao X, Li C and Fu Y: microRNA-21 overexpression contributes to cell proliferation by targeting PTEN in endometrioid endometrial cancer. Oncol Lett 4: 1290-1296, 2012.

65. Ramón LA, Braza-Boïls A, Gilabert J, Chirivella M, España F, Estellés A and Gilabert-Estellés J: microRNAs related to angiogenesis are dysregulated in endometrioid endometrial cancer. Hum Reprod 27: 3036-3045, 2012.

66. Romero-Pérez L, Castilla MA, López-García MA, Díaz-Martín J, Biscuola M, Ramiro-Fuentes S, Oliva E, Matias-Guiu X, Prat J, Cano A, et al: Molecular events in endometrial carcinosarcomas and the role of high mobility group AT-hook 2 in endometrial carcinogenesis. Hum Pathol 44: 244-254, 2013.

67. Shan ZN, Tian R, Zhang M, Gui ZH, Wu J, Ding M, Zhou XF and $\mathrm{He} \mathrm{J}$ : miR128-1 inhibits the growth of glioblastoma multiforme and glioma stem-like cells via targeting BMI1 and E2F3. Oncotarget 7: 78813-78826, 2016.

68. Shang C, Lu YM and Meng LR: MicroRNA-125b downregulation mediates endometrial cancer invasion by targeting ERBB2. Med Sci Monit 18: BR149-BR155, 2012.

69. Torres A, Kozak J, Korolczuk A, Wdowiak P, DomańskaGlonek E, Maciejewski $\mathrm{R}$ and Torres $\mathrm{K}$ : In vitro and in vivo activity of miR-92a-Locked Nucleic Acid (LNA)-inhibitor against endometrial cancer. BMC Cancer 16: 822, 2016.

70. Tsukamoto O, Miura K, Mishima H, Abe S, Kaneuchi M, Higashijima A, Miura S, Kinoshita A, Yoshiura K and Masuzaki H: Identification of endometrioid endometrial carcinoma-associated microRNAs in tissue and plasma. Gynecol Oncol 132: 715-721, 2014

71. Wang J, Li Y, Ding M, Zhang H, Xu X and Tang J: Molecular mechanisms and clinical applications of miR-22 in regulating malignant progression in human cancer (Review). Int J Oncol 50: 345-355, 2017. (Review).

72. Yang N, Kaur S, Volinia S, Greshock J, Lassus H, Hasegawa K, Liang S, Leminen A, Deng S, Smith L, et al: MicroRNA microarray identifies Let-7i as a novel biomarker and therapeutic target in human epithelial ovarian cancer. Cancer Res 68 10307-10314, 2008.

73. Zhang R, He Y, Zhang X, Xing B, Sheng Y, Lu H and Wei Z: Estrogen receptor-regulated microRNAs contribute to the BCL2/ BAX imbalance in endometrial adenocarcinoma and precancerous lesions. Cancer Lett 314: 155-165, 2012.

74. Zhao C, Wang G, Zhu Y, Li X, Yan F, Zhang C, Huang X and Zhang Y: Aberrant regulation of miR-15b in human malignant tumors and its effects on the hallmarks of cancer. Tumour Biol 37: 177-183, 2016.

75. Zhao H, Xu Z, Qin H, Gao Z and Gao L: miR-30b regulates migration and invasion of human colorectal cancer via SIX1. Biochem J 460: 117-125, 2014.

76. Nishida M: The Ishikawa cells from birth to the present. Hum Cell 15: 104-117, 2002.

77. Pfaffl MW, Tichopad A, Prgomet C and Neuvians TP: Determination of stable housekeeping genes, differentially regulated target genes and sample integrity: BestKeeper-Excel-based tool using pair-wise correlations. Biotechnol Lett 26: 509-515, 2004

78. Chou CH, Chang NW, Shrestha S, Hsu SD, Lin YL, Lee WH, Yang CD, Hong HC, Wei TY, Tu SJ, et al: miRTarBase 2016 Updates to the experimentally validated miRNA-target interactions database. Nucleic Acids Res 44: D239-D247, 2016.

79. Fang JS, Gillies RD and Gatenby RA: Adaptation to hypoxia and acidosis in carcinogenesis and tumor progression. Semin Cancer Biol 18: 330-337, 2008.

80. Gatenby RA and Gillies RJ: Why do cancers have high aerobic glycolysis? Nat Rev Cancer 4: 891-899, 2004.

81. Gatenby RA, Smallbone K, Maini PK, Rose F, Averill J, Nagle RB, Worrall L and Gillies RJ: Cellular adaptations to hypoxia and acidosis during somatic evolution of breast cancer. Br J Cancer 97: 646-653, 2007.

82. Sameni M, Mullins S, Moin K, Sloane B and Osuala K: Importance of the tumor microenvironment. In: Breast Cancer Metastasis and Drug Resistance: Progress and Prospects. Ahmad A (ed). Springer, New York, pp178-179, 2013. 
83. Dews M,Homayouni A, Yu D, Murphy D, Sevignani C, Wentzel E, Furth EE, Lee WM, Enders GH, Mendell JT, et al: Augmentation of tumor angiogenesis by a Myc-activated microRNA cluster. Nat Genet 38: 1060-1065, 2006.

84. Suárez Y, Fernández-Hernando C, Yu J, Gerber SA, Harrison KD, Pober JS, Iruela-Arispe ML, Merkenschlager M and Sessa WC: Dicer-dependent endothelial microRNAs are necessary for postnatal angiogenesis. Proc Natl Acad Sci USA 105: 14082-14087, 2008.

85. Lei Z, Li B, Yang Z, Fang H, Zhang GM, Feng ZH and Huang B: Regulation of HIF-1alpha and VEGF by miR-20b tunes tumor cells to adapt to the alteration of oxygen concentration. PLoS One 4: e7629, 2009.

86. Danza K, Silvestris N, Simone G, Signorile M, Saragoni L, Brunetti O, Monti M, Mazzotta A, De Summa S, Mangia A, et al: Role of miR-27a, miR-181a and miR-20b in gastric cancer hypoxia-induced chemoresistance. Cancer Biol Ther 17: 400-406, 2016.

87. Chen PH, Cheng CH, Shih CM, Ho KH, Lin CW, Lee CC, Liu AJ, Chang CK and Chen KC: The inhibition of microRNA-128 on IGF-1-activating mTOR signaling involves in Temozolomideinduced glioma cell apoptotic death. PLoS One 11: e0167096, 2016.

88. Stefani G and Slack FJ: Small non-coding RNAs in animal development. Nat Rev Mol Cell Biol 9: 219-230, 2008

89. Takamizawa J, Konishi H, Yanagisawa K, Tomida S, Osada H, Endoh H, Harano T, Yatabe Y, Nagino M, Nimura Y, et al: Reduced expression of the let-7 microRNAs in human lung cancers in association with shortened postoperative survival. Cancer Res 64: 3753-3756, 2004.
90. Tsuji T, Umekita Y, Ohi Y, Kamio M, Douchi T and Yoshida H: Maspin expression is up-regulated during the progression of endometrioid endometrial carcinoma. Histopathology 51: 871-874, 2007.

91. Mirra P, Raciti GA, Nigro C, Fiory F, D'Esposito V, Formisano P, Beguinot $\mathrm{F}$ and Miele $\mathrm{C}$ : Circulating miRNAs as intercellular messengers, potential biomarkers and therapeutic targets for Type 2 diabetes. Epigenomics 7: 653-667, 2015.

92. Turchinovich A, Samatov TR, Tonevitsky AG and Burwinkel B: Circulating miRNAs: Cell-cell communication function? Front Genet 4: 119, 2013.

93. Gambari R, Brognara E, Spandidos DA and Fabbri E: Targeting oncomiRNAs and mimicking tumor suppressor miRNAs: New trends in the development of miRNA therapeutic strategies in oncology (Review). Int J Oncol 49: 5-32, 2016.

94. Bai JX, Yan B, Zhao ZN, Xiao X, Qin WW, Zhang R, Jia LT, Meng YL, Jin BQ, Fan DM, et al: Tamoxifen represses miR-200 microRNAs and promotes epithelial-to-mesenchymal transition by up-regulating c-Myc in endometrial carcinoma cell lines. Endocrinology 154: 635-645, 2013.

95. Shen Y, Lu L, Xu J, Meng W, Qing Y, Liu Y, Zhang B and $\mathrm{Hu} \mathrm{H}$ : Bortezomib induces apoptosis of endometrial cancer cells through microRNA-17-5p by targeting p21. Cell Biol Int 37: 1114-1121, 2013. 